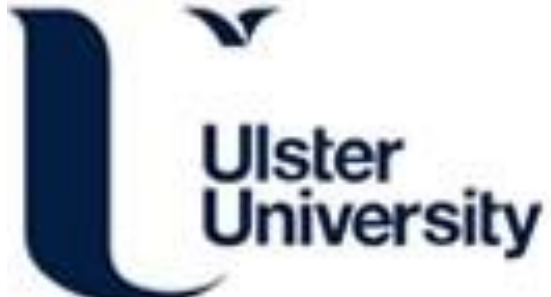

\section{Assessing the risk of phosphorus transfer to high ecological status rivers: Integration of nutrient management with soil geochemical and hydrological conditions}

Roberts, W. M., Gonzalez-Jimenez, J. L., Doody, D. G., Jordan, P., \& Daly, K. (2017). Assessing the risk of phosphorus transfer to high ecological status rivers: Integration of nutrient management with soil geochemical and hydrological conditions. Science of the Total Environment, 589, 25 - 35.

https://doi.org/10.1016/j.scitotenv.2017.02.201

Link to publication record in Ulster University Research Portal

Published in:

Science of the Total Environment

Publication Status:

Published online: 03/03/2017

DOI:

10.1016/j.scitotenv.2017.02.201

\section{Document Version}

Author Accepted version

\section{General rights}

Copyright for the publications made accessible via Ulster University's Research Portal is retained by the author(s) and / or other copyright owners and it is a condition of accessing these publications that users recognise and abide by the legal requirements associated with these rights.

\section{Take down policy}

The Research Portal is Ulster University's institutional repository that provides access to Ulster's research outputs. Every effort has been made to ensure that content in the Research Portal does not infringe any person's rights, or applicable UK laws. If you discover content in the Research Portal that you believe breaches copyright or violates any law, please contact pure-support@ulster.ac.uk. 
1 Assessing the risk of phosphorus transfer to high ecological status rivers:

2 Integration of nutrient management with soil geochemical and hydrological

3 conditions.

4

5 William M. Roberts ${ }^{\mathrm{a}}$, Jose L. Gonzalez-Jimenez ${ }^{\mathrm{a}, \mathrm{b}}$, Donnacha G. Doody ${ }^{\mathrm{c}}$, Philip $6 \quad$ Jordan $^{\mathrm{d}}$ and Karen Daly ${ }^{\mathrm{a}}$

$7 \quad{ }^{a}$ Teagasc, Environmental Research Centre, Johnstown Castle, Wexford, Ireland

8 ' $N a t i o n a l$ University of Ireland, University Road, Galway, Co. Galway

$9{ }^{\mathrm{c}}$ Agri-Food and Biosciences Institute, Newforge Lane, Belfast, BT9 5PQ, UK

$10{ }^{\mathrm{d}}$ School of Geography and Environmental Sciences, University of Ulster, 11 Coleraine, BT52 1SA, UK

12

13

14 " Corresponding author: Tel.: +353 9171283 E-mail address:

$15 \quad$ karen.daly@teagasc.ie (K.Daly).

16

17

18

19

20 Keywords: Phosphorus, agriculture, high ecological status, nutrient 21 management, soil type, organic matter. 
24 Agriculture has been implicated in the loss of pristine conditions and ecology at river sites 25 classified as at 'high ecological status' across Europe. Although the exact causes remain unclear, diffuse phosphorus (P) transfer warrants consideration because of its wider

27 importance for the ecological quality of rivers. This study assessed the risk of P loss at field 28 scale from farms under contrasting soil conditions within three case-study catchments 29 upstream of near-pristine river sites. Data from 39 farms showed P surpluses were common 30 on extensive farm enterprises despite a lower $\mathrm{P}$ requirement and level of intensity. At field 31 scale, data from 520 fields showed that Histic topsoils with elevated organic matter contents 32 had low $\mathrm{P}$ reserves due to poor sorption capacities, and received applications of $\mathrm{P}$ in excess of 33 recommended rates. On this soil type $67 \%$ of fields recorded a field P surplus of between 1 34 and $31 \mathrm{~kg} \mathrm{ha}^{-1}$, accounting for $46 \%$ of fields surveyed across 10 farms in a pressured high 35 status catchment. A P risk assessment combined nutrient management, soil biogeochemical 36 and hydrological data at field scale, across 3 catchments and the relative risks of $\mathrm{P}$ transfer 37 were highest when fertilizer quantities that exceeded current recommendations on soils with a 38 high risk of mobilization and high risk of transport as indicated by topographic wetness index 39 values. This situation occurred on $21 \%$ of fields surveyed in the least intensively managed 40 catchment with no on-farm nutrient management planning and soil testing. In contrast, the 41 two intensively managed catchments presented a risk of $\mathrm{P}$ transfer in only $3 \%$ and $1 \%$ of 42 fields surveyed across 29 farms. Future agri-environmental measures should be administered 43 at field scale, not farm scale, and based on soil analysis that is inclusive of OM values on a 44 field-by-field basis. 


\section{Introduction}

Diffuse, non-point pollution remains a major threat to surface waters due to eutrophication caused by nitrogen $(\mathrm{N})$ and phosphorus $(\mathrm{P})$ transfers originating, in part, from agricultural land (Carpenter et al., 1998; EEA, 2012; OECD, 2008). In Ireland, phosphorus (P) transfer from agricultural land has been asserted as the primary cause of degradation in $53 \%$ of the river water bodies that failed to achieve 'good' ecological status under the WFD (Byrne and Fanning, 2015). However, it is difficult to make the same assertion about rivers that are at risk of failing to maintain 'high' ecological status due to the uncertainty around the causes of degradation (Irvine and $\mathrm{N}^{\prime}{ }^{\prime}$ Chuanigh, 2013; Roberts et al., 2016) and also due to natural variations in high status conditions (Irvine, 2004). Nevertheless, P transfer from agriculture does warrant consideration given its wider importance for the ecological quality of rivers.

In productive agricultural systems, nutrient transfer to surface water can be conceptualized along a continuum from source, via mobilization and delivery, to impact (Haygarth et al., 2005). Sources of $P$ include native soil $P$ or $P$ applied in excess of crop demand that can be mobilized during the initial separation of $\mathrm{P}$ molecules from their source via geochemical desorption, biological solubilisation, or physical detachment. These processes can be increased under certain soil conditions and managements (Daly et al., 2001; McDowell et al., 2001). From the point of mobilisation, $\mathrm{P}$ is transported via subsurface or surface pathways, depending on soil hydrological conditions, until it is "delivered" to the water where it can have an "impact" by stimulating excessive algal growth (Beven et al., 2005; Haygarth et al., 2005).

In the European Union (EU), designations under the Water Framework Directive (WFD OJEC, 2000) include those water bodies deemed at 'high status', i.e. not deviating from pristine or reference conditions according to ecological classifications (Pardo et al., 2012), 
and which may be particularly sensitive to any external pressure (del Mar Sánchez-Montoya et al., 2012). The number of high status water bodies varies across the EU either due to a natural dearth of water body types or due to ubiquitous impacts that reduce the percentage number overall (Table 1 - EEA, 2012). Ireland and Austria stand out as particularly rich member states in terms of both the number of water bodies (7,401 and 5,670, respectively) and percentage at high status (both at $18 \%$ ). The WFD requires member states to maintain high status water bodies and convergence to at least good status for all other water bodies using the same harmonised ecological classification system (ECOSTAT, 2003). This harmonization is based on all EU member states calibrating biological indicators with physico-chemical parameters and based on river typologies.

81 A key concept underlying the WFD is the integration of existing water policies such as the Nitrates Directive (OJEC, 1991) which is designed to improve water quality by regulating onfarm nutrient use and reduce nutrient and sediment losses to water. To transpose this complex legislation into law, each EU member state must implement measures through a Nitrates Action Programme (NAP) either in specific zones or on a whole territory basis (OJEC, 1991). For example, Ireland's NAP sets limits on $\mathrm{P}$ use and requires farms to maintain a zero farm-gate $\mathrm{P}$ balance with optimised soil test $\mathrm{P}$ (Morgan's $\mathrm{P}<8 \mathrm{mg} \mathrm{l}^{-1}$ ) values across the farm (SI 31 of 2014). On intensive farms these measures have resulted in reducing $\mathrm{P}$ balances at farm scale and reducing the occurance of fields with excessive soil test $\mathrm{P}$ values; however, they fail to account for soil geochemical and hydrological conditions that 91 vary spatially across the agricultural landscape. High ecological status river catchments located in upland areas with a mosaic of mineral and organic soils support a mix of extensive and intensive farm enterprises (Irvine and $\mathrm{N}^{\prime}$ Chuanigh, 2013; White et al., 2014). Whilst current legislation regulates nutrient use at farm scale, agri-environmental measures in these 
areas need to take account of soil geochemical and hydrological variation at smaller scales

(field) to minimize nutrient losses to water and maintain high ecological status.

97 Grassland agriculture in Irish high status catchments varies greatly in extent from being completely absent to covering up to $88 \%$ of catchment areas. The latter catchments are at the highest risk of failing to maintain high ecological status (Roberts et al., 2016). However, several studies have found a high proportion of fields on low intensity farms with excessive P levels due to surplus P applications over time (Gibbons et al., 2014; Schulte et al., 2009). This risk of $\mathrm{P}$ transfer would be elevated further when $\mathrm{P}$ surpluses are applied to $\mathrm{P}$ saturated soils and soils with poor P retention capacities. Grassland soils that cannot assimilate added P and build up $\mathrm{P}$ reserves for draw down by a growing crop have been characterised in Ireland and elsewhere (refs). These include soils with a high \% of organic matter (OM) in the surface horizon and categorised here as Histic topsoils. High organic matter content in the surface horizon of soils occludes sorption sites on clay minerals and competes with P for sorption, thereby reducing the soils $\mathrm{P}$ sorption capacity and $\mathrm{P}$ retention. The implications for $\mathrm{P}$ management on these soils centers on their low P sorption capacity which prevents build-up

110 of $\mathrm{P}$ reserves onto the soil matrix. Instead, $\mathrm{P}$ remains in the soil solution and added fertiliser $\mathrm{P}$ 111 is susceptible to leaching and runoff (Daly et al., 2001; Guppy et al., 2005). In addition, if

112 these soils coincide with conditions that promote saturation excess overland flow such as

113 high water tables, large contributing areas and shallow slopes (Beven and Kirkby, 1979;

114 Holden, 2006), there is likely to be a high potential for P transport to streams. However, the 115 importance of these factors have not always been fully appreciated in previous risk 116 assessments or nutrient management approaches for P transfer, which may have, in part, led

117 to the perception that only intensive agriculture with high fertilizer inputs and high stocking 118 rates and/or tillage frequencies can pose a threat to aquatic ecosystems (Doody et al., 2014, 119 2012; Watson et al., 2009). 
120 Building on this background the objectives of this research were to 1) characterise the

121 geochemical and hydrological setting for agriculture in high status catchments in Ireland, and

122 2) assess current nutrient management at field scale and the relative risk of $P$ loss under

123 different biogeochemical and hydrological condition. To address these objectives, field-scale

124 nutrient management data and soil geochemical and hydrological characteristics were 125 collected from 520 fields surveyed within three case study catchments. Field-scale P 126 requirements, $\mathrm{P}$ applications, and $\mathrm{P}$ balances were examined along with field characteristics 127 and combined in a field based risk assessment scheme to explore the extent to which current 128 nutrient management practice poses a risk in high status catchments.

\section{Methods}

\subsection{Characterisation of high status catchments}

132 Three case study catchments were selected from an existing database on 508 high status

133 catchments delineated in Roberts et al. (2016). Catchment selection used a simple multicriteria decision approach to represent agriculture on the dominant soils across the wider high status catchment population. Of the 508 high status catchments those that had monitoring

136 sites situated below $200 \mathrm{~m}$ in elevation and on river segments with Strahler stream orders

137 ranging from 2 to 5 were selected for further analysis. Further analysis was initially by Kmeans cluster analysis, which aims to partition observations into a number of pre-specified clusters in which each observation belongs to the cluster with the nearest mean. In this case,

140 K-means cluster analysis was used to identify the three main groups of catchments based on

141 soils mapped and categoried in Teagasc/EPA Indicative Soils Map

142 (http://gis.epa.ie/GetData/Download). These were characterised by a high percentage cover of 143 either, poorly drained acid mineral/peaty mineral soils, well-drained acid mineral soils, and 
144 peat soils as previously mapped in the Teagasc/EPA soils and subsoils map, and these are

145 listed in Table 2. To help select the three study catchments and to ensure they were

146 agriculturally pressured, the 356 catchments were ranked by percentage agricultural cover

147 three times, each time in combination with one of the three soil classes. The final three

148 catchments were selected by expert judgement by avoiding excessively large or small

149 catchments, catchments in inaccessible locations, and those with large urban areas or

150 industrial workings; these were the River Allow in County Cork, the River Black in County

151 Galway/Mayo and the River Urrin in County Wexford (Figure 1).

152 The upstream catchment of the River Allow is dominated by poorly drained surface water 153 gleys underlain by siliceous drift and shale bedrock with blanket peat in the upland areas 154 toward the river's source (Figure 2). The catchment of the River Black is dominated by well 155 drained brown earth mineral soils underlain by calcareous drift and limestone geology but 156 interspersed with large areas of lowland raised bog peat (Figure 2). Situated in the south east, 157 the River Urrin catchment is dominated by well drained acid brown earth, mineral soils 158 underlain by siliceous drift and shale and slate geology, blanket peat exist in the upland areas 159 near to the source of the river (Figure 2).

160 Land use is dominated by grassland agriculture which covers 66,63 and $41 \%$ of the Rivers 161 Allow, Black and Urrin catchments, respectively. For nutrient management purposes, grazing 162 intensity in Ireland is calculated as the total annual nitrogen $(\mathrm{kg})$ excreted by grazing 163 livestock averaged over the net grassland area (grazing and silage area). $85 \mathrm{~kg}$ of organic 164 nitrogen $(\mathrm{ON})$ excreted annually equates to 1 livestock unit per hectare in the traditional 165 measurement. Catchment grazing intensities are 115, 90 and $61 \mathrm{~kg} \mathrm{ON} \mathrm{ha}{ }^{-1} \mathrm{yr}^{-1}$, which 166 equates to approximately 18,14 and $9 \mathrm{~kg}$ organic $\mathrm{P} \mathrm{ha}^{-1} \mathrm{yr}^{1}$, for the Rivers Allow, Black and 
167 Urrin, respectively. The grassland coverage and stocking rate are lower in the River Urrin

168 catchment due to the presence of arable land (30\%) (Figure 2).

\subsection{Farm surveys}

171 In total 10, 13 and 16 farm surveys were completed in the Allow, Black and Urrin

172 catchments, respectively, to gather soil samples and information on farm and field nutrient

173 management practices. These farms were selected to represent the range of farming systems

174 present. The farms selected were also spatially distributed across the catchments to reduce the

175 possibility for spatial auto-correlation between farm and field-scale measurements. Farmers

176 were initially contacted through a national advisory network (Teagasc, The Irish Agriculture

177 and Food Research Authority) and then through word of mouth, which meant that some

178 participating farmers had no prior contact with advisory services or researchers. Across the

17939 farms surveyed, a total of 520 fields (195 in the Allow, 112 in the Black, and 213 in the

180 Urrin catchments), were sampled and records of $\mathrm{P}$ management were assessed. This data

181 represented 11, 3 and $9 \%$ of agricultural land in the rivers Allow, Black and Urrin

182 catchments being surveyed, respectively. Thus the data reported here is not on a whole

183 catchment basis, rather on a whole-farm basis and field-by-field basis on farms under the unique biogeochemical and hydrological settings of the selected catchments.

185 Soil samples were collected from each field over the 2014/2015 winter whilst ensuring at

186 least six weeks since the last fertilizer application to allow suitable time for equilibration of

187 fertilizer P with the soil (Agbenin and Tiessen, 1995; Vadas et al., 2007). However, farmers

188 reported spreading $90 \%$ of fertilizers during spring and summer leaving ample time for equilibration before sampling. Spreading of fertilizers was almost always by surface 
broadcasting but arable farmers often incorporated fertilizers into the soil and occasionally

191 placed fertilizer granules with seeds. The fields were sampled by collecting at least 20 soil

192 cores using a bucket sampler to $10 \mathrm{~cm}$ depth in a 'W' pattern across the field avoiding

193 gateways and dung patches (SI 31, 2014). The cores were then composited, dried at $40{ }^{\circ} \mathrm{C}$

194 and sieved to $2 \mathrm{~mm}$ prior to laboratory analysis for chemical properties. Morgan P was used 195 to estimate soil P (plant available) status, which involves extracting $6.5 \mathrm{ml}$ of soil with a

196 buffered $(\mathrm{pH}=4.8)$ acetate-acetic acid reagent at a 1:5 $(\mathrm{v} / \mathrm{v})$ soil to solution ratio for $30 \mathrm{~min}$ 197 and then analysed colorimetrically using a Camspec UV-VIS spectrometer (Byrne 1979;

198 Morgan 1941). Soil $\mathrm{pH}$ was determined in deionised water at a 1:2 soil to solution ratio using

199 a Jenway pH meter with glass electrodes. Organic matter (OM) contents were determined by 200 loss on ignition using $5 \mathrm{~g}$ samples ignited for 4 hours in a Northerm muffle furnace at $400{ }^{\circ} \mathrm{C}$.

201 Total $\mathrm{P}$ was determined on $1 \mathrm{~g}$ sample suspended in $2 \mathrm{ml}$ deionized water followed by a 202 reagent combination of $7.5 \mathrm{ml}$ nitric acid (69\%) and $2.5 \mathrm{ml}$ concentrated hydrolchloric acid.

203 Sample digestion was carried out using microwave digestion using MARS6 microwave after 204 which samples were filtered and analysed using an Agilent inductively coupled plasma spectrometer to determine TP content. This method (Kingston and Haswell, 1997) was performed on a subset of samples categorised as Histic topsoil $(n=62)$ and mineral $(n=88)$

207 across all catchments.

\subsection{Field scale nutrient management}

210 To calculate field $\mathrm{P}$ requirements, use and balances, records collected from each field

211 surveyed and included, organic and chemical fertilizer inputs, farm stocking densities and

212 feed concentrate use were obtained from the farmers through a semi-structured interview and

213 integrated with soil test $\mathrm{P}$ results to estimate field $\mathrm{P}$ requirements, applications and balances. 
214 These were based on current advisory fertilizer guidelines, which form the basis of Ireland's

215 National Action Programme (NAP) of measures to regulate fertilizer use for the Nitrates

216 Directive (Coulter and Lalor, 2008). Morgan's soil P is used in Ireland for agronomic advice

217 with levels categorised as indices; 1 (deficient), 2 (low), and 3 (agronomic optimum) and 4

218 (excessive) (Coulter and Lalor, 2008). The magnitude of the rates prescribed are dependent

219 on this P index and also on factors such as farming system, intensity, organic matter contents and crop type (Coulter \& Lalor 2008) the limits are described in footnotes to Table 4. The P requirement for each field is then determined as the rate identified minus feed concentrate $\mathrm{P}$ used per hectare of the farm. A P balance can then be calculated by then subtracting the actual amounts of $\mathrm{P}$ applied to individual fields as organic and chemical fertilizers to give the final balance (Murphy et al., 2015; Wall et al., 2012). These parameters were also calculated at farm scale to examine farm gate $\mathrm{P}$ balances for each farm surveyed.

226 Evidence of poaching, the damage caused to turf by the feet of livestock, was noted whilst sampling the fields These observations were then considered in relation to soil drainage properties as inferred from the Irish EPA/Teagasc Soils and Subsoils Map Indicative Soil Map (http://gis.epa.ie/GetData/Download).

Topographic wetness index (TWI - Beven and Kirkby, 1979) was calculated in ArcGIS and considered as a factor promoting $\mathrm{P}$ transport since slope and contributing area are key for generating saturation excess overland flow, a common generation process in temperate agricultural landscape settings (Heathwaite et al., 2005; Peukert et al., 2014). The topographic wetness index at which soil saturation actually occurs varies between studies due calculation methods or natural factors such as soil water storage capacity and preferential flow pathways, but typically occurs above the median value of indices across study areas

237 (Leh et al., 2008; Rodhe and Seibert, 1999). For this reason, maximum TWI was determined 
for each field and the arbitrary threshold value for separating the fields with the driest and wettest areas was the $75^{\text {th }}$ percentile of TWI values across the three catchments (hereafter termed 'runoff potential').

\subsection{Field P risk assessments}

243 Soil biochemical data, hydrological condition and agronomic management data for 520 fields were combined into a risk assessment scheme was to assess the relative risk of edge-of-field losses of $\mathrm{P}$ from each field based on source, mobilization and transport factors. The risk assessment included the field $\mathrm{P}$ balance as the source factor, percentage organic matter and evidence of poaching or erosion as mobilisation factors, and topographic wetness index (TWI) and surface drainage as transport factors and are described in Table 3. Each factor was assigned a weighting in terms of relative risk and combined to produce a risk score for each field. Previous field risk assessments typically only use the absolute amount of fertilizer applied to estimate the risk due to applications (e.g. Hughes et al., 2005; Lemunyon and Gilbert, 1993; Sharpley et al., 2003), which may have previously biased source risks towards intensive farms. However, because the amount of $\mathrm{P}$ required to replace plant offtakes (soil $\mathrm{P}$ requirement) varies depending on field management, a $\mathrm{P}$ balance approach that takes account of this may be a more accurate indicator of over-application of P. Percentage organic matter was included as a mobilisation risk factor as those soils with more than $20 \%$ organic matter

257 have a reduced capacity adsorb any excess P applied and build up P reserves.

258 Assigning the risk from surface drainage involved summing the drainage density (total length 259 as percentage of field perimeter) of streams, sloping surface ditches ( $>5 \%$ slope) and flat surface ditches $(<5 \%$ slope $)$, on the premise that higher drainage density indicates greater connectivity and a reduced potential for overland flow to re-infiltrate (Shore et al., 2013).

262 Streams were given the highest weight (1) to reflect the risk of fields having a direct 
connection, sloping ditches were given an intermediate weighting (0.6) and flat ditches were

264 given the lowest (0.3) as some sediments and P may be retained (Shore et al., 2015). Those

265 fields scoring above the $75^{\text {th }}$ percentile of drainage risk scores were assigned a high risk for

266 surface drainage due to increased connectivity (Table 3).

267 Transport factors were given equal or lower weightings than source factors in many previous assessments (Lemunyon and Gilbert, 1993; e.g. Magette et al., 2007), but here overland flow risk was given the highest weighting to reflect the realisation that hydrology may be dominant in P transfer (Buda et al., 2009; Jordan et al., 2012; Mellander et al., 2015).

271 Conversely, the connectivity risk due to surface drainage features was given a lower

272 weighting as fields can still be connected in the absence of these features. Finally, to

273 determine the overall risk score for each field, the risk score for each factor was multiplied by 274 the factor weighting, the resulting risk scores for mobilisation factors were summed as were 275 those for transport factors and then the resulting risk score for source, mobilisation and 276 transport were multiplied in ArcGIS.

\subsection{Data and statistical analysis}

To examine the differences in nutrient management on fields with different biogeochemical and hydrological properties, statistical linear modelling included 'OM' and 'TWI' with two levels each as fixed factors. However, the data were arranged in a hierarchical structure as

282 fields were nested within farms and farms were nested within catchments. This design often

283 leads to spatial dependence, for example, fields in one farm or catchment are more similar among each other in P management than to fields on another farm or catchment due to spatial location. To account for this spatial structure, 'farm' and 'catchment' were included in the model as random factors in a nested structure to separate their effects from those of OM and 
TWI. An interaction term was also included to test whether P management on fields with differing OM contents and TWI values varied depending on the catchment. All analyses were carried out using R statistical software (Version 3.2.2) with the 'nlme' and 'Lme4' packages (Bates 2010; Pinheiro et al. 2017). Results were considered significant when probability values were equal to or less than 0.05 .

\section{Results}

\subsection{Farm scale nutrient management planning within the case study catchments}

Farm scale data are presented in Table 4. The farms surveyed in the River Black catchment ranged in size from 17 to 56 ha with an average farm size of 34 ha and were limited to mixed cattle and sheep farms with a low average grazing intensity $\left(96 \mathrm{~kg} \mathrm{ON} \mathrm{ha}^{-1}\right.$ ranging from 57 to $129 \mathrm{~kg} \mathrm{ON} \mathrm{ha}^{-1}$ ). This was in contrast to the larger farm size and greater enterprise diversity observed in the Allow (dairy enterprises and cattle enterprises ranging in size from 11 to 84 ha with an average size of 46 ha and grazing intensity of $155 \mathrm{~kg} \mathrm{ON} \mathrm{ha}^{-1}$ ranging from 69 to $243 \mathrm{~kg} \mathrm{ON} \mathrm{ha}{ }^{-1}$ ) and River Urrin catchments (dairy, cattle, cattle and sheep, arable, and arable and sheep farms ranging in size from 15 to 78 ha with an average size of 39 ha and average grazing intensity of $154 \mathrm{~kg} \mathrm{ON} \mathrm{ha}^{-1}$ ranging from 43 to $250 \mathrm{~kg} \mathrm{ON} \mathrm{ha}^{-1}$.

303 The results from the farm surveys revealed that none of the ten farmers participating in the river Black catchment had up-to-date nutrient management plans based on soil testing, whereas 8 of the 13 and 11 of the 16 farmers surveyed in the Allow and Urrin catchments, respectively, did. This was mainly because dairy farmers were farming at grazing intensities

307 above $170 \mathrm{~kg} \mathrm{ON} \mathrm{ha}^{-1}$ and soil testing is mandatory at this intensity. This was reflected in 308 their farm gate $\mathrm{P}$ balances in which most of the farms in Allow and Urrin catchments recorded negative $\mathrm{P}$ balances (Table 4). In contrast, 6 of the 10 farms in the Black catchment recorded positive farm gate $\mathrm{P}$ balances, despite a lower $\mathrm{P}$ requirement and level of intensity at 
311 farm scale. At this scale, the P requirement was lowest for farms in the Black catchment, and

312 highest for those in the Urrin catchments, possibly due to the presence of cropping systems in

313 the Urrin which have higher P requirements for arable crops than grassland. Despite good

314 uptake of soil testing on farms in the Allow and Urrin catchments, soil pH was suboptimum

315 in $89 \%$ of surveyed fields and the distribution of $\mathrm{P}$ around the fields within farms according

316 to nutrient guidelines was poor in all catchments, indicating poor adoption and

317 implementation of plans where they existed.

\subsection{Field scale soil $P$ and $P$ management}

320 Nutrient management and soil data at field scale are presented in Table 4 and follow a

321 broadly similar pattern to farm scale observations in $\mathrm{P}$ balances and requirement. Compared to the other two catchments, fields in the Black catchment had lower P requirements largely due to lower grazing intensities, as mentioned earlier, but also because of the presence of

324 Histic topsoils on these farms. These soils are characterised with poor $\mathrm{P}$ retention and 325 sorption capacities, with $>20 \% \mathrm{OM}$ in the top $10 \mathrm{~cm}$ as previously reported by Daly et al.

326 (2001). Soil OM analysis allowed for the identification of these fields across the farms surveyed.

328 Using the complete field dataset, Morgan $\mathrm{P}, \mathrm{P}$ applications, $\mathrm{P}$ requirement and $\mathrm{P}$ balance were delineated for both mineral $(\leq 20 \%$ OM) and Histic topsoils $(>20 \%$ OM) for statistical

330 linear modelling and these values are displayed in Table 5. Although the surveyed fields

331 represented only a relatively small sample of fields from the catchments, the observed 332 differences in P management on fields with delineated as mineral and Histic topsoil (based on means and standard errors) were validated statistically by linear modelling. The P 
requirement of the fields dominated by Histic topsoils were significantly lower than for those dominated by mineral soils because of lower grazing intensities, and because of limitations on $\mathrm{P}$ applications on this soil type. Fields characterised as Histic topsoils have lower $\mathrm{P}$ recommendations than mineral soils and current recommended $\mathrm{P}$ applications on Histic topsoils is limited to application that replace $\mathrm{P}$ removed in crop offtakes, known as 'maintenance rates'.

340 Despite this, these fields received applications in excess of the advised maintenance rates and

341 hence had increased and largely positive $\mathrm{P}$ balances (Table 5). When nutrient management is

342 displayed by OM contents within each catchment (Figure 3) the highest number of Histic 343 topsoils soils were found in the River Black catchment indicating highest risk of $\mathrm{P}$ mobilization from farms under these catchment conditions. Across the fields surveyed in the Black catchment, $\%$ OM ranged from 8 to $91 \%$, with $46 \%$ of fields surveyed categorized as

346 Histic topsoils with $>20 \%$ OM. The absence of field-by-field soil testing to identify parts of 347 the farm where Histic topsoils occur coupled with a lack of nutrient management planning, 348 led to over applications of $\mathrm{P}$ which resulted in positive farm gate and field $\mathrm{P}$ balances in the 349 Black catchment. Across the 10 farms surveyed in this catchment, $65 \%$ of fields with Histic 350 topsoils recorded field $\mathrm{P}$ balances, in surplus, ranging from 1 to $31 \mathrm{~kg} \mathrm{ha}^{-1}$.

351 Statistical analysis also indicated significantly higher Morgan's P values recorded in Histic 352 topsoils (Table 5) compared to mineral soils with $<20 \%$ OM. In the subset of soils analysed 353 for total P, Morgan P results for Histic topsoils soils ranged from 1.4 to $40.3 \mathrm{mg}^{-1}$ with a 354 mean value of $9.8 \mathrm{mg} \mathrm{l}^{-1}$ indicating higher $\mathrm{P}$ status in these soils compared to mineral soils 355 whose values ranged from 0.9 to $29.5 \mathrm{mg} \mathrm{l}^{-1}$, with a mean of $4.9 \mathrm{mg} \mathrm{l}^{-1}$. High Morgan's $\mathrm{P}$ 356 values typically indicates build-up of $\mathrm{P}$ with values above $8 \mathrm{mg} \mathrm{l}^{-1}$ indicative of elevated soil

$357 \mathrm{P}$ and high P reserves in mineral soils. However, TP concentrations for Histic topsoils ranged 
358 from 65 to $1235 \mathrm{mg} \mathrm{l}^{-1}$ (mean: $505 \mathrm{mg} \mathrm{l}^{-1}$ ), lower than concentrations for mineral soils which

359 ranged from 308 to $1754 \mathrm{mg} \mathrm{l}^{-1}$ (mean: $797 \mathrm{mg} \mathrm{l}^{-1}$ ). In addition, TP and Morgan's P were

360 correlated in mineral soils $(\mathrm{r}=0.84, P<0.001)$, however there was no significant correlation

361 (Pearson) between $P$ parameters values in Histic topsoils $(\mathrm{r}=0.00, P>0.05)$ (Figure 4). These

362 findings indicate a lack of accumulation as $\mathrm{P}$ reserves in Histic top soils due to their low 363 sorption capacities and P retention. This indicates that Morgan's P test is over-estimating P

364 availability and accumulation, possibly because organic $\mathrm{P}$ forms are hydrolysed by the acid

365 matrix of the reagent. In addition, it is suggested here that soluble organic matter in the

366 Morgan's extract may cause interference with the colorimetric step which affects the

367 accuracy of the test for agronomic recommendations. Morgan $\mathrm{P}$ test is therefore not 368 appropriate for soils where $\% \mathrm{OM}>20$ at the surface $10 \mathrm{~cm}$, and does not provide an accurate reflection of $\mathrm{P}$ status and for $\mathrm{P}$ balance estimates in nutrient management planning

\subsection{Soil hydrological conditions influencing P loss risk}

372 The mobilisation potential associated with poaching was lowest in the extensively farmed

373 River Black catchment since only one of the surveyed fields showed clear evidence of

374 poaching. However, 11 and $6 \%$ of the fields surveyed in the River Allow and Urrin catchments exhibited evidence of poached soils, respectively; typically occurring around gateways, feeding and drinking troughs, and points where cattle could access the stream.

377 Specific field survey data were also investigated by TWI indices which theoretically

378 esstimated the driest and wettest fields. Field data was separated by TWI and data for Morgan

379 P, P requirement, $\mathrm{P}$ applied and $\mathrm{P}$ balance for the driest and wettest soils are shown in Table

380 5. Statistical linear modelling indicated that in the overall data and within individual 
catchments, Morgan $\mathrm{P}, \mathrm{P}$ requirements, $\mathrm{P}$ use, and $\mathrm{P}$ balances were similar on fields with driest soils as they were on fields with the wettest soils, as confirmed by probability values greater than 0.05 for main effects and interactions (Table 5). When calculated at field scale, these estimates indicated that the river Black catchment showed the highest number of fields with a high runoff potential $(n=54)$ followed by the Allow catchment $(n=48)$ and then the

386 Urrin catchment $(n=30)$. When calculated at whole catchment scale, TWI means and 387 medians also followed this same order as above. Compared to the other two catchments, slopes are relatively shallow and contributing areas large in the River Black catchment, and the large areas of lowland raised bog are also indicative of wet conditions. In both the Allow and Urrin catchments, where slopes were steeper, wetness indices were generally highest around tributary streams, and in the Allow catchment also around the shallow slopes of the flood plain of the main stem of the river, a landscape feature that was much less defined in the Urrin catchment.

394 Artificial and natural surface drainage features also increased $\mathrm{P}$ transfer risk by potentially 395 increasing connectivity between any overland flow generated and the stream. As a result, 48, 39637 and $18 \%$ of fields surveyed in the Rivers Allow, Black and Urrin catchments, 397 respectively, achieved high drainage risk scores in the assessment. Risks were most elevated 398 in the River Allow catchment due to shallow ditches, steep ditches and streams surrounding 399 an average of $6.3 \%, 4.0 \%$ and $7.3 \%$ of field perimeters, respectively. There were no steep 400 ditches observed in the River Black catchment, but an average of 12.4 and $5.3 \%$ of field 401 perimeters were bordered by shallow ditches and streams, respectively. Although the artificial 402 drainage density was extremely low in the River Urrin catchment the overall risks were elevated due to an average of $3.9 \%$ of field perimeters being bordered by streams. 
407 Fields surveyed in the River Black catchment had the highest median and widest range of 408 field risk scores, followed by fields in the River Allow Catchment and then those in the River 409 Urrin catchment (Figure 5). The highest risks were assumed where elevated $\mathrm{P}$ sources (P 410 index 4 or positive $\mathrm{P}$ balances), a high potential for mobilisation (Histic soils or poached 411 soils) and a high potential for transport (high TWI indices indicating high runoff potential) 412 combined to form critical source areas, a situation that occurred in 3,21 and $1 \%$ of surveyed 413 fields in the Allow, Black and Urrin, respectively. Inside those areas mean values of 414 Morgan's P, P balance, OM and TWI were $11.8 \mathrm{mg} \mathrm{l}^{-1}, 7.5 \mathrm{~kg} \mathrm{ha}^{-1}, 44.2 \%$ and 17.9, 415 respectively, compared outside of those areas where they were $5.1 \mathrm{mg} \mathrm{l}^{-1},-6.0 \mathrm{~kg} \mathrm{ha}^{-1}, 13.9 \%$ 416 and 14.1, respectively.

\section{4. Discussion}

419 Based on a carefully selected series of case study of catchments, this study shows that 420 agriculture in pressured high ecological status catchments is not limited to intensive farming 421 but instead exists at a range of intensities and systmes that vary greatly within and between catchments. In this present study the spatial analysis of high status catchments in Ireland revealed a mix of well-drained and poorly drained mineral soils and Histic topsoils with elevated $\%$ OM values at the surface. In this data, OM ranged from $5 \%$ to $91 \%$ which has implication for the assimilation and retention of added $\mathrm{P}$ and the risk of $\mathrm{P}$ loss to water. Risks of $\mathrm{P}$ transfer were present across these ranges, but were particularly high within the River Black catchment, which contained the lower intensity drystock farms. Schulte et al. (2009) uncovered a similar situation in the Lough Melvin catchment, Northern Ireland, a catchment 
with a grazing intensity of approximately $41 \mathrm{~kg} \mathrm{ON} \mathrm{ha}^{-1}$, where $31 \%$ of fields surveyed

430 posed a high risk of $\mathrm{P}$ transfer (using the risk assessment approach of Magette et al. (2007)).

\subsection{Nutrient management practice in high status catchments}

432 The adoption of soil testing and farm nutrient management plans also varied, with none of the

433 farms in the most extensively farmed Black catchment currently using soil testing or nutrient

434 management planning as a tool to manage nutrients, whereas most of the farms in the more intensively farmed catchment had adopted nutrient management planning based on soil testing.

437 Phosphorus applications above the recommended rates were common in the extensively 438 managed River Black catchment on Histic topsoils as indicated by positive P balances. While 439 other studies indicate that farm-scale $\mathrm{P}$ balances in Ireland have declined since the 440 introduction of the Nitrates Directive measures (Buckley et al., 2016; Mihailescu et al., 2015;

441 Ruane et al., 2043), the results of this study showed that positive P balances occurred when 442 nutrient management failed to take account of soil type, specifically, soils with $\mathrm{OM}>20 \%$ 443 within the agronomic depth for soil sampling. In line with previous studies (Wall et al., 2012) 444 poor nutrient management and the absence of on-farm nutrient management planning gave 445 rise to poor distribution of nutrients across the farm resulting in fields with excessively high $\mathrm{P}$ 446 values receiving P applications. Previous studies focusing on intensively farmed agricultural 447 catchments, with predominantly mineral soils, have demonstrated that elevated soil P levels 448 can be corrected with regular soil testing and nutrient management planning. However, this 449 approach will only work in high status catchments if soil analysis for agronomic 450 recommendations includes \% OM testing on a field-by-field basis so that Histic topsoils can 451 be identified from mineral soils and on-farm nutrient management tailored for soil type. 
453 Nutrient management planning and the regulation of $\mathrm{P}$ use on farms is inextricably linked 454 with soil testing, however, this has resulted in an over-reliance of testing for $\mathrm{P}$ and $\mathrm{pH}$ only to 455 guide nutrient applications and record farm-gate P balances. Relying on Morgan's P values 456 alone, without including organic matter values, masks the effect of soil type on recommended 457 P rates, $\mathrm{P}$ balance and $\mathrm{P}$ loss risk as illustrated by the data collected in this study. Where soil samples exhibit $>20 \% \mathrm{OM}$ current nutrient management guidelines recommend $\mathrm{P}$ applications that replace crop offtakes, and prohibits build-up rates on these soils, due to poor P sorption capacities (Coulter and Lalor, 2008; Daly et al., 2001). An important step towards accounting for this issue has been the incorporation of $\mathrm{OM}$ into fertilizer recommendations in

462 Ireland and in other European countries (Amery and Schoumans, 2014; Coulter and Lalor, 2008; Jordan-Meille et al., 2012). In Ireland rates of $\mathrm{P}$ that replace $\mathrm{P}$ removed in crop offtakes, known as maintenance rates are permitted, however, the occurance of Histic topsoils across farms in high status catchments will only be identified by soil sampling and analysis that includes $\% \mathrm{OM}$ as a parameter. Soil analysis that does not include \% OM will not allow

467 for delineation of Histic topsoils on the farm and will lead to misguided over-applications of $\mathrm{P}$ to these soils. For mineral soils $\mathrm{P}$ applications are guided by soil test $\mathrm{P}$ levels and corresponding P index, however, as there is currently no P index system for Histic topsoils, rates of $\mathrm{P}$ applied rely on the inclusion of $\% \mathrm{OM}$ in soil analytical suites.

472 Positive P balances on Histic topsoils occurred in $67 \%$ of fields surveyed and ranged from 473 surpluses of between 1 and $31 \mathrm{~kg} \mathrm{P} \mathrm{ha}^{-1}$. The reasons for this were two-fold: Firstly, the absence of soil testing to identify the occurance of these soils across the farm and secondly, the lack of nutrient management plans to guide $\mathrm{P}$ application meant that $\mathrm{P}$ was applied in 
excess of recommended rates, often at rates typically applied to build-up soil $\mathrm{P}$ reserves on

477 mineral soil. Losses of applied P from these soils can be high, for example, McDowell and Monaghan (2015) studied P losses from managed pastures on podzol and peat soils in New Zealand. Although P loads from the podzol soils were high $\left(>8 \mathrm{~kg} \mathrm{ha}^{-1}\right)$ over the 18 month study period, they were extreme from the peat soil $\left(80 \mathrm{~kg} \mathrm{ha}^{-1}\right)$ equalling $89 \%$ of the fertilizer P applied. Previous studies in Ireland and elsewhere (Daly et al., 2001; Guppy et al., 2005) 482 have characterised these soils with low $\mathrm{P}$ sorption capacities and poor $\mathrm{P}$ retention due to competitive reactions between organic matter and $\mathrm{P}$ on the surface of clay minerals. This means that these soils cannot build up $\mathrm{P}$ reserves and retain added $\mathrm{P}$ through the physicochemical reactions that typically happen in mineral soils. The results from this study demonstrated an absence of accumulation in total P concentrations for Histic topsoils despite the application of $\mathrm{P}$ build-up rates indicative of these soils inability to build up P reserves and their potential for high P losses of applied P (Simmonds et al., 2015).

\subsection{Field Soil hydrological conditions in high status catchments}

491
The Allow catchment recorded a relatively higher incidence of soil disturbance by poaching of soil by livestock. Amongst other effects poaching of the soil damages the protective cover that would otherwise be provided by vegetation and therefore leaves the soil vulnerable to erosion (Bilotta et al., 2008; Haygarth et al., 2012; McDowell et al., 2003). For example, on a hillslope in the UK the removal of the vegetation cover through severe poaching led to an increase in the rate of suspended sediment and total phosphorus delivery in overland flow by 30 and 16 times, respectively (Heathwaite et al., 1990). Poorly drained soils are most susceptible (Creamer et al., 2010; Heathwaite et al., 1990), and fields in the Allow catchment 
where these soils were common and grazing intensities high, showed the greatest incidence of

500 poaching, increasing the risk of sediment delivery into streams and rivers.

501 Shallow sloping topography and large contributing areas promote saturation excess overland

502 flow (Agnew et al., 2006; Beven and Kirkby, 1979), which is further exacerbated by poorly

503 drained soils (Buda et al., 2009; Needelman et al., 2004). In terms of P transfer, these

504 hydrological factors are thought to over-ride the effects of management. For example, Buda et al. (2009) measured P in runoff from small plots and found that overland flow volumes and

P loads were larger at foot slope positions compared to at upslope positions where legacy soil

$\mathrm{P}$ concentrations and therefore $\mathrm{P}$ concentrations in runoff were high, but runoff volumes were much lower. This has also been observed at the catchment scale, where catchments with

509 flashy hydrographs, yet with lower P sources, showed the greatest stream P loads (Basset, 2010; Jordan et al., 2012; Mellander et al., 2015). Despite this importance, no European

511 country's fertilizer guidelines currently consider soil hydrological conditions as a risk factor

512 (Amery and Schoumans, 2014; Jordan-Meille et al., 2012), and hence field P management 513 appeared to be similar on the driest soils as it was on the wettest soils. Although outside of 514 nutrient management recommendations, current Irish NAP measures discourage the 515 spreading of fertilizers on wet and sloping areas of the farm, but there is currently no formal 516 method to identify such areas and adjust management accordingly.

\section{4.4 Field scale risk assessment in high status catchments}

518 Across the three catchments, the assessed relative risks of $\mathrm{P}$ transfer from fields was higher

519 from fields located within the extensively farmed River Black catchment, as evidenced by the 520 high proportion fields where high source, mobilisation and transport potentials coincided. 521 Schulte et al. (2009) proposed a similar situation in the Irish Lough Melvin catchment with a 522 grazing intensity of approximately $41 \mathrm{~kg} \mathrm{ON} \mathrm{ha}^{-1}$, where $31 \%$ of fields surveyed posed a 
high risk of $\mathrm{P}$ transfer due to over-application of slurry to drier fields and a resulting build-up of soil $\mathrm{P}$ above agronomic optimum levels. These results are in contrast to the intensively farmed River Urrin catchment, where the number of fields showing high risks were consistently fewer for all $\mathrm{P}$ transfer factors individually and combined ( $1 \%$ of fields surveyed). Overall, these data question the perception that only intensive agriculture can pose

528 a P risk to water quality and suggests that if research and policy places more focus on specific farming systems that are considered to be intensive there will be a risk of non-compliance especially in the context of maintaining high ecological status at river sites. Although this risk assessment served well to compare relative risk between catchments and fields, as with all field scale P risk assessments, there is a great deal of uncertainty around how well the measured risk actually reflects absolute risk. For example, there are a lack of data from Irish studies measuring P loss from agricultural fields with which to validate risk assessments (Hughes et al., 2005), the national DEM resolution was insufficient in resolution to identify

536 flow sinks created by micro-topographic features that cause overland flow to become disconnected (Thomas et al., 2016) and TWI alone does not account for the soil water storage

538 capacity, which, when low, can increase overland flow risk (Quinn et al., 1995; Walter et al., 2002). However, the greatest uncertainty relates to the issue of scale, and specifically, around how well risks identified at field scale are realized in water quality and ecological status at catchment scales.

\section{Conclusions and recommendations}

544 This study characterised the soil geochemical and hydrological properties of farms in high status catchments in Ireland and examined field scale nutrient management and the relative risk of P loss from fields, under different soil conditions Low adoption of soil testing and 
nutrient management planning on extensive farms led to increased risks of $\mathrm{P}$ transfer on

548 Histic topsoils when application of $\mathrm{P}$ sources failed to account for soil conditions that 549 promote the mobilisation and transport of $\mathrm{P}$ such as highly organic matter and wet soils. 550 Furthermore, the risk assessment based on fields surveyed revealed that the catchment, with 551 the highest occurance of Histic topsoils, (wet soil) posed the greatest risk of P loss, based on positive $\mathrm{P}$ balances and fields with high \% OM. Current EU water policy measures for agriculture centers on nutrient management planning and soil testing on intensive farms, however, this study has illustrated the need for better nutrient use efficiency on extensive grassland farms on marginalized land. To increase nutrient use efficiency and reduce P loss risk and based on the results of this study the following recommendation include:

- Regular soil testing to monitor soil $\mathrm{P}$ and $\mathrm{pH}$ on should be used to optimize nutrient management on mineral soils, but not be relied upon for nutrient management on Histic topsoils.

- Extensive farm enterprises in high status catchments should have access to soil information on \% $\mathrm{OM}$ on a field-by-field basis. Organic matter testing at high spatial resolution need only be carried out once to establish which parts of the farm are comprised of mineral and Histic topsoils. This will ensure that nutrient management is soil type specific and will restore P surpluses to balance at both field and farm scale.

- Hydrologically sensitive areas within high status river catchments could be delineated using simple topographic indices as done here, and the timing and rates of $\mathrm{P}$ applications tailored to account for risk, as is the case for high OM soils.

- Agricultural measures for high status catchments will need to be administered at field scale (not farm scale) with the aid of appropriate soil geochemical and hydrological data at this scale. 
- Future agri-environmental schemes under the EU Common Agricultural Policy and Rural Development Programme could consider providing \% OM surveys on a fieldby-field basis to farms in high status catchments.

\section{Acknowledgements:}

This research was funded by the Irish Department of Agriculture Forestry and the Marine in Ireland under the Research Stimulus Fund 2013 (project refernece 13/S/488). The authors would like to thank the farmers who participated in this study and provided access to land and fertiliser records. The support of laboratory staff at Teagasc Johnstown Castle is greatly appreciated.

\section{References}

Agbenin, J.O., Tiessen, H., 1995. Phosphorus sorption at field capacity and soil ionic strength: Kinetics and transformation. Soil Science Society of America Journal 59, 998-1005. doi:10.2136/sssaj1995.03615995005900040006x

Agnew, L.J., Lyon, S., Gérard-Marchant, P., Collins, V.B., Lembo, A.J., Steenhuis, T.S., Walter, M.T., 2006. Identifying hydrologically sensitive areas: Bridging the gap between science and application. Journal of Environmental Management 78, 63-76. doi:http://dx.doi.org/10.1016/j.jenvman.2005.04.021

Amery, F., Schoumans, O.F., 2014. Agricultural phosphorus legislation in Europe. ILVO, Merelbeke, Belgium.

Basset, A., 2010. Aquatic science and the water framework directive: a still open 
challenge towards ecogovernance of aquatic ecosystems. Aquatic doi:10.1002/aqc.1117

Beven, K., Heathwaite, L., Haygarth, P., Walling, D., Brazier, R., Withers, P., 2005. On the concept of delivery of sediment and nutrients to stream channels. Hydrological Processes 19, 551-556. doi:10.1002/hyp.5796

Beven, K.J., Kirkby, M.J., 1979. A physically based, variable contributing area

600 model of basin hydrology. Hydrological Sciences Bulletin 24, 43-69.

601 doi:10.1080/02626667909491834

Bilotta, G.S., Brazier, R.E., Haygarth, P.M., Macleod, C.J.A., Butler, P., Granger, S., Krueger, T., Freer, J., Quinton, J., 2008. Rethinking the

604 Contribution of Drained and Undrained Grasslands to Sediment-Related

605 Water Quality Problems. Journal of Environmental Quality 37.

606 doi:10.2134/jeq2007.0457

Buckley, C., Wall, D.P., Moran, B., O’Neill, S., Murphy, P.N.C., 2016.

608 Phosphorus management on Irish dairy farms post controls introduced under the $\{\mathrm{EU}\}$ Nitrates Directive. Agricultural Systems 142, 1-8.

610 doi:http://dx.doi.org/10.1016/j.agsy.2015.10.007

611 Buda, A.R., Kleinman, P.J.A., Srinivasan, M.S., Bryant, R.B., Feyereisen, G.W., 612 2009. Effects of hydrology and field management on phosphorus transport 613 in surface runoff. Journal of Environmental Quality 38, 2273-2284.

614 doi:0.2134/jeq2008.0501 
615 Byrne, C., Fanning, A., 2015. Water quality in Ireland (2010-2012).

616 Environmental Protection Agency, Johnstown Castle, Wexford, Ireland.

617 Carpenter, S.R., Caraco, N.F., Correll, D.L., Howarth, R.W., Sharpley, A.N., 618 Smith, V.H., 1998. Nonpoint pollution of surface waters with phosphorus 619 and nitrogen. Ecological Applications 8, 559-568. doi:10.1890/1051-

620 0761(1998)008[0559:nposww]2.0.co;2

621 Coulter, B., Lalor, S., 2008. Major and micro nutrient advice for productive 622 agricultural crops, 3rd ed. Teagsc, Johnstown Castle, Wexford, Ireland.

Creamer, R.E., Brennan, F., Fenton, O., Healy, M.G., Lalor, S.T.J., Lanigan, G.J., Regan, J.T., Griffiths, B.S., 2010. Implications of the proposed Soil Framework Directive on agricultural systems in Atlantic Europe - a review. Soil Use and Management 26, 198-211. doi:10.1111/j.1475-

627 2743.2010.00288.x

Daly, K., Jeffrey, D., Tunney, H., 2001. The effect of soil type on phosphorus sorption capacity and desorption dynamics in Irish grassland soils. Soil Use and Management 17, 12-20. doi:10.1111/j.1475-2743.2001.tb00003.x

del Mar Sánchez-Montoya, M., Arce, M.I., Vidal-Abarca, M.R., Suárez, M.L., Prat, N., Gómez, R., 2012. Establishing physico-chemical reference conditions in Mediterranean streams according to the European Water Framework Directive. Water Research 46, 2257-2269. doi:http://dx.doi.org/10.1016/j.watres.2012.01.042 
uncertainty in declining water quality in an extensively farmed grassland

638 catchment. Environmental Science \& Policy 24, 15-23.

639 doi:http://dx.doi.org/10.1016/j.envsci.2012.07.007

640

641

642

643

644

645

646

647

648

649

650

651

652

653

654

655

656

657

658

Doody, D.G., Withers, P.J.A., Dils, R.M., 2014. Prioritizing waterbodies to balance agricultural production and environmental outcomes. Environmental Science \& Technology 48, 7697-7699. doi:10.1021/es5024509

ECOSTAT, 2003. Overall Approach to the Classification of Ecological Status and Ecological Potential. Water Framework Directive Common Implementation Strategy Working Group 2 A Ecological Status. ECOSTAT, Rome, Italy.

EEA, 2012. European waters - assessment of status and pressures. Office for Official Publications of the European Union, Luxembourg.

Gibbons, J.M., Williamson, J.C., Williams, A.P., Withers, P.J.A., Hockley, N., Harris, I.M., Hughes, J.W., Taylor, R.L., Jones, D.L., Healey, J.R., 2014. Sustainable nutrient management at field, farm and regional level: Soil testing, nutrient budgets and the trade-off between lime application and greenhouse gas emissions. Agriculture, Ecosystems \& Environment 188, 48-56. doi:http://dx.doi.org/10.1016/j.agee.2014.02.016

Guppy, C.N., Menzies, N.W., Moody, P.W., Blamey, F.P.C., 2005. Competitive sorption reactions between phosphorus and organic matter in soil: a review. Soil Research 43, 189-202. doi:http://dx.doi.org/10.1071/SR04049

Haygarth, P.M., Condron, L.M., Heathwaite, A.L., Turner, B.L., Harris, G.P., 

2005. The phosphorus transfer continuum: Linking source to impact with an interdisciplinary and multi-scaled approach. Science of The Total Environment 344, 5-14.

662 doi:http://dx.doi.org/10.1016/j.scitotenv.2005.02.001

663

664

665

666

667

668

669

670

671

672

673

674

675

676

677

678

679

680

Haygarth, P.M., Page, T.J.C., Beven, K.J., Freer, J., Joynes, A., Butler, P., Wood, G.A., Owens, P.N., 2012. Scaling up the phosphorus signal from soil hillslopes to headwater catchments. Freshwater Biology 57, 7-25. doi:10.1111/j.1365-2427.2012.02748.x

Heathwaite, A.L., Burt, T.P., Trudgill, S.T., 1990. The effect of land use on nitrogen, phosphorus and suspended sediment delivery to streams in a small catchment in southwest England, in: Thornes, J.B. (Ed.), Vegetation and Erosion. Processes and Environments. John Wiley and Sons, Chichester, UK, pp. 161-177.

Heathwaite, A.L., Quinn, P.F., Hewett, C.J.M., 2005. Modelling and managing critical source areas of diffuse pollution from agricultural land using flow connectivity simulation. Journal of Hydrology 304, 446-461. doi:http://dx.doi.org/10.1016/j.jhydrol.2004.07.043

Holden, J., 2006. Peatland hydrology, in: Martini, I.P., Martínez-Cortizas, A., Chesworth, W. (Eds.), Developments in Earth Surface Processes: Peatlands — Evolution and Records of Environmental and Climate Changes. Elsevier Science, Amsterdam, Netherlands, pp. 319-346.

Hughes, K.J., Magette, W.L., Kurz, I., 2005. Identifying critical source areas for phosphorus loss in Ireland using field and catchment scale ranking schemes. 
Irvine, K., 2004. Classifying ecological status under the European Water Framework Directive: the need for monitoring to account for natural variability. Aquatic Conservation: Marine and Freshwater Ecosystems 14, 107-112. doi:10.1002/aqc. 622

Irvine, K., N1' Chuanigh, E., 2013. Management strategies for the protection of high status waterbodies: a literature review. Environmental Protection Agency, Johnstown Castle, Wexford, Ireland.

Jordan-Meille, L., Rubæk, G.H., Ehlert, P.A.I., Genot, V., Hofman, G., Goulding, K., Recknagel, J., Provolo, G., Barraclough, P., 2012. An overview of fertilizer-P recommendations in Europe: soil testing, calibration and fertilizer recommendations. Soil Use and Management 28, 419-435. doi:10.1111/j.1475-2743.2012.00453.x

Jordan, P., Melland, A.R., Mellander, P.E., Shortle, G., Wall, D., 2012. The seasonality of phosphorus transfers from land to water: Implications for trophic impacts and policy evaluation. Science of The Total Environment 434, 101-109. doi:http://dx.doi.org/10.1016/j.scitotenv.2011.12.070

Kingston, H.M., Haswell, S.J., 1997. Microwave-Enhanced Chemistry: Society, Washington, DC. 
Delineating runoff processes and critical runoff source areas in a pasture billslope of the Ozark Highlands. Hydrological Processes 22, 4190-4204.

706 doi:10.1002/hyp.7021

707

708

709

710

711

712

713

714

715

716

717

718

Lemunyon, J.L., Gilbert, R.G., 1993. The concept and need for a phosphorus assessment tool. Journal of Production Agriculture 6, 483-486.

Magette, W.L., Hallissey, R., Hughes, K., Cosgrove, E., 2007. Eutrophication from agricultural sources: field- and catchment-scale risk assessment. Environmental Protection Agency, Johnstown Castle, Wexford, Ireland.

McDowell, R.W., Drewry, J.J., Muirhead, R.W., Paton, R.J., 2003. Cattle treading and phosphorus and sediment loss in overland flow from grazed cropland. Soil Research 41, 1521-1532. doi:http://dx.doi.org/10.1071/SR03042

McDowell, R.W., Monaghan, R.M., 2015. Extreme Phosphorus Losses in Drainage from Grazed Dairy Pastures on Marginal Land. Journal of Environmental Quality 44, 545-551. doi:10.2134/jeq2014.04.0160

McDowell, R.W., Sharpley, A.N., Condron, L.M., Haygarth, P.M., Brookes, P.C., 2001. Processes controlling soil phosphorus release to runoff and implications for agricultural management. Nutrient Cycling in Agroecosystems 59, 269-284. doi:10.1023/A:1014419206761

Mellander, P.-E., Jordan, P., Shore, M., Melland, A.R., Shortle, G., 2015. Flow paths and phosphorus transfer pathways in two agricultural streams with contrasting flow controls. Hydrological Processes 29, 3504-3518. 
727

728

729

730

731

732

733

734

735

736

737

738

739

740

741

742

743

744

745

746

747

Mihailescu, E., Murphy, P.N.C., Ryan, W., Casey, I.A., Humphreys, J., 2015. Phosphorus balance and use efficiency on 21 intensive grass-based dairy farms in the South of Ireland. The Journal of Agricultural Science 153, 520537. doi:10.1017/S0021859614000641

Murphy, P.N.C., Mellander, P.E., Melland, A.R., Buckley, C., Shore, M., Shortle, G., Wall, D.P., Treacy, M., Shine, O., Mechan, S., Jordan, P., 2015. Variable response to phosphorus mitigation measures across the nutrient transfer continuum in a dairy grassland catchment. Agriculture, Ecosystems \& Environment 207, 192-202. doi:http://dx.doi.org/10.1016/j.agee.2015.04.008

Needelman, B.A., Gburek, W.J., Petersen, G.W., Sharpley, A.N., Kleinman, P.J.A., 2004. Surface Runoff along Two Agricultural Hillslopes with Contrasting Soils. Soil Science Society of America Journal 68. doi: $10.2136 /$ sssaj2004.9140

OECD, 2008. Environmental Performance of Agriculture in OECD Countries since 1990. OECD, Paris, France.

OJEC, 2000. Council Directive 2000/60/EEC of 23 October 2000 of the European Parliament and of the Council: Establishing a Framework for Community Action in the Field of Water Policy. Official Journal of the European Community.

OJEC, 1991. Council Directive 91/676/EEC of 12 December 1991 Concerning 

the Protection of Waters Against Pollution Caused by Nitrates from Agricultural Sources. Official Journal of the European Community.

750

751

752

753

754

755

756

757

758

759

760

761

762

763

764

765

766

767

768

769

770

Pardo, I., Gómez-Rodríguez, C., Wasson, J.-G., Owen, R., van de Bund, W., Kelly, M., Bennett, C., Birk, S., Buffagni, A., Erba, S., Mengin, N., MurrayBligh, J., Ofenböeck, G., 2012. The European reference condition concept: A scientific and technical approach to identify minimally-impacted river ecosystems. Science of The Total Environment 420, 33-42. doi:http://dx.doi.org/10.1016/j.scitotenv.2012.01.026

Peukert, S., Griffith, B.A., Murray, P.J., Macleod, C.J.A., Brazier, R.E., 2014. Intensive Management in Grasslands Causes Diffuse Water Pollution at the Farm Scale. J. Environ. Qual. 43, 2009-2023. doi:10.2134/jeq2014.04.0193

Pinheiro J, Bates D, DebRoy S, Sarkar D and R Core Team (2017). nlme: Linear and Nonlinear Mixed Effects Models. R package version 3.1-131, https:/CRAN.Rproject.org $/$ package $=$ nlme .

Quinn, P.F., Beven, K.J., Lamb, R., 1995. The Ln(a/Tan-Beta) index-how to calculate it and how to use it within the TOPMODEL framework. Hydrological Processes 9, 161-182. doi:10.1002/hyp.3360090204

Roberts, W.M., Fealy, R.M., Doody, D.G., Jordan, P., Daly, K., 2016. Estimating the effects of land use at different scales on high ecological status in Irish rivers. Science of The Total Environment. doi:http://dx.doi.org/10.1016/j.scitotenv.2016.04.011

Rodhe, A., Seibert, J., 1999. Wetland occurrence in relation to topography: A test of topographic indices as moisture indicators. Agricultural and Forest 
772

773

774

775

776

777

778

779

780

781

782

783

784

785

786

787

788

789

790

791

792

Ruane, E.M., Treacy, M., Lalor, S., Watson, C.J., Humphreys, J., 2043. Farmgate phosphorus balances and soil phosphorus concentrations on intensive dairy farms in the south-west of Ireland. Irish Journal of Agricultural and Food Research 53, 105-119.

Schulte, R.P.O., Doody, D.G., Byrne, P., Cockerill, C., Carton, O.T., 2009. Lough Melvin: Developing cost-effective measures to prevent phosphorus enrichment of a unique aquatic habitat. Irish Journal of Agri-environmental Research 7, 211-228.

Sharpley, A.N., Weld, J.L., Beegle, D.B., Kleinman, P.J.A., Gburek, W.J., Moore, P.A., Mullins, G., 2003. Development of phosphorus indices for nutrient management planning strategies in the United States. Journal of Soil and Water Conservation 58, 137-152.

Shore, M., Jordan, P., Mellander, P.E., Kelly-Quinn, M., Melland, A.R., 2015. An agricultural drainage channel classification system for phosphorus management. Agriculture, Ecosystems \& Environment 199, 207-215. doi:http://dx.doi.org/10.1016/j.agee.2014.09.003

Shore, M., Murphy, P.N.C., Jordan, P., Mellander, P.E., Kelly-Quinn, M., Cushen, M., Mechan, S., Shine, O., Melland, A.R., 2013. Evaluation of a surface hydrological connectivity index in agricultural catchments. Environmental Modelling \& Software 47, 7-15. doi:http://dx.doi.org/10.1016/j.envsoft.2013.04.003 
Simmonds, B.M., McDowell, R.W., Condron, L.M., Jowett, T., 2015. Potential phosphorus losses from organic and podzol soils: prediction and the influence of soil physico-chemical properties and management. New Zealand Journal of Agricultural Research 58, 170-180. doi: $10.1080 / 00288233.2014 .988830$

Thomas, I.A., Jordan, P., Mellander, P.E., Fenton, O., Shine, O., Ó hUallacháin, D., Creamer, R., McDonald, N.T., Dunlop, P., Murphy, P.N.C., 2016. Improving the identification of hydrologically sensitive areas using LiDAR DEMs for the delineation and mitigation of critical source areas of diffuse pollution. Science of The Total Environment 556, 276-290. doi:http://dx.doi.org/10.1016/j.scitotenv.2016.02.183

Vadas, P.A., Harmel, R.D., Kleinman, P.J.A., 2007. Transformations of soil and manure phosphorus after surface application of manure to field plots. Nutrient Cycling in Agroecosystems 77, 83-99. doi:10.1007/s10705-006$9047-5$

Wall, D.P., Murphy, P.N.C., Melland, A.R., Mechan, S., Shine, O., Buckley, C., Mellander, P.E., Shortle, G., Jordan, P., 2012. Evaluating nutrient source regulations at different scales in five agricultural catchments. Environmental Science \& Policy 24, 34-43. doi:http://dx.doi.org/10.1016/j.envsci.2012.06.007

Walter, T.M., Steenhuis, T.S., Mehta, V.K., Thongs, D., Zion, M., Schneiderman, E., 2002. Refined conceptualization of TOPMODEL for shallow subsurface flows. Hydrological Processes 16, 2041-2046. 
817 Watson, N.M., Heathwaite, A.L., Maberly, S., Norton, L., Waterton, C.,

818 Tsouvalis, J., Haygarth, P.M., 2009. Integrated Catchment Management and

819 the WFD; dealing with the complexity and uncertainty of diffuse pollution

820 from agriculture. Tearmann 7, 195-210.

821 White, B., Moorkens, E., Irvine, K., Glasgow, G., Chuanigh, E.N., 2014.

822 Management strategies for the protection of high status water bodies under the Water Framework Directive. Biology and Environment: Proceedings of the Royal Irish Academy 114B, 129-142. doi:10.3318/BIOE.2014.25

\section{Figure Captions}

Figure 1. Ireland, showing county boundaries (Republic of Ireland) and the location and characteristics of the three case study catchments. Average annual rainfall and temperature are Met Éireann 10 year averages.

830

Figure 2. Agricultural land use (A) and soil classes (B) in the three case study catchments.

834 Figure 3. Mean Morgan P (A), P requirement (B), $\mathrm{P}$ applied (C) and $\mathrm{P}$ balance (D) by organic matter contents within each catchment showing standard error bars. The number of samples ( $n)$ used for summarising those variables were as follows: River Allow - OM $\leq 20 \%, n=184$; River Allow - OM $>20$ 
$\%, n=11$; River Black - OM $\leq 20 \%, n=61$; River Black - OM $>20 \%, n=51$;

841 Figure 4. Scatterplots of soil TP and Morgan P by organic matter (OM) contents (Mineral soils: $\leq 20 \%$ OM; Histic topsoils: $>20 \%$ OM). Pearson's r correlation was only significant $(\mathrm{r}=0.84, \mathrm{P}<0.001)$ for mineral soils.

844

Figure 5. Box (25, 50 and 75 percentiles) and whisker (1.5 x interquartile range) plots of the risk scores by catchment.

847

848

849

850

851

852

853

854

855

856

857

858

859

860

861

862

863

864

865

866

867

868

869

870

871

872

873

874

875

876 
877 Table 1. EU member state water body numbers, percentage and river length at

878 high status (EEA, 2012 - www.eea.europa.eu/data-and-

$879 \quad$ maps/data/wise wfd-european-data).

880

\begin{tabular}{lcccccc}
\hline $\begin{array}{l}\text { EU Member } \\
\text { State }\end{array}$ & $\begin{array}{c}\text { Number of } \\
\text { water bodies }\end{array}$ & $\begin{array}{c}\text { Number at } \\
\text { High } \\
\text { Status }\end{array}$ & $\begin{array}{c}\text { Percentage } \\
\text { at High } \\
\text { Status }\end{array}$ & $\begin{array}{c}\text { Total } \\
\text { length }\end{array}$ & $\begin{array}{c}\text { Length } \\
\text { at High } \\
\text { Status }\end{array}$ & $\begin{array}{c}\text { Percentage } \\
\text { at High } \\
\text { Status }\end{array}$ \\
\hline Malta & 9 & 4 & 44.4 & 0 & 0 & 0 \\
Slovakia & 1760 & 487 & 27.7 & 18944 & 3786 & 20 \\
Lithuania & 1183 & 287 & 24.3 & 14251 & 2605 & 18.3 \\
Croatia & 1315 & 281 & 21.4 & 13041 & 1800 & 13.8 \\
Austria & 7401 & 1332 & 18.0 & 31393 & 4291 & 13.7 \\
Ireland & 5670 & 1012 & 17.8 & 21039 & 1864 & 8.9 \\
Finland & 6153 & 681 & 11.1 & 28875 & 4659 & 16.1 \\
Sweden & 23418 & 2043 & 8.7 & 79467 & 6181 & 7.8 \\
Spain & 5124 & 425 & 8.3 & 82276 & 5396 & 6.6 \\
Slovenia & 155 & 11 & 7.1 & 2619 & 168 & 6.4 \\
Greece & 1689 & 112 & 6.6 & 13030 & 206 & 1.6 \\
France & 11523 & 747 & 6.5 & 241684 & 10881 & 4.5 \\
Denmark & 15988 & 965 & 6.0 & 18842 & 1436 & 7.6 \\
Portugal & 1945 & 94 & 4.8 & 598575 & 79628 & 13.3 \\
Bulgaria & 759 & 36 & 4.7 & 25569 & 862 & 3.4 \\
Romania & 3399 & 145 & 4.3 & 74473 & 2346 & 3.2 \\
United & 10961 & 441 & 4.0 & 99748 & 1653 & 1.7 \\
Kingdom & & & & & & \\
Cyprus & 260 & 8 & 3.1 & 2579 & 0 & 0 \\
Latvia & 470 & 14 & 3.0 & 7752 & 535 & 6.9 \\
Estonia & 750 & 12 & 1.6 & 12107 & 295 & 2.4 \\
Belgium & 560 & 7 & 1.2 & 9309 & 95 & 1 \\
Italy & 8614 & 91 & 1.1 & 78812 & 655 & 0.8 \\
Poland & 5643 & 52 & 0.9 & 111485 & 749 & 0.7 \\
Germany & 9863 & 76 & 0.8 & 126158 & 152 & 0.1 \\
Hungary & 1082 & 5 & 0.5 & 18802 & 0 & 0 \\
Czech & 1140 & 0 & 0.0 & 18596 & 0 & 0 \\
Republic & & & & & & \\
Netherlands & 724 & 0 & 0.0 & 4757 & 0 & 0 \\
Luxembourg & 102 & 0 & 0.0 & 0 & 0 & 0 \\
\hline & & & & & & \\
\hline
\end{tabular}

881

882 
884 Table 2. Results of K-means clustering analysis showing mean soil class

885

886

887

\begin{tabular}{lcccc}
\hline Cluster number: & 1 & 2 & 3 \\
$(n=158)$ & $(n=102)$ & $\begin{array}{c}\text { Overall } \\
(n=96\end{array}$ & $(n=356)$ \\
\hline
\end{tabular}

Soil class $(\%$ coverage $)$ :

Alluvium

Acid mineral poorly drained

Acid mineral well drained

Basic mineral poorly drained

Basic mineral well drained

Acid peaty mineral poorly drained

Basic peaty mineral unclassified

drainage

Basic peaty mineral poorly drained

Peat

2.15

1.32

3.09

2.17

26.23

11.21

11.94

18.07

14.59

4.42

66.16

25.58

1.54

1.60

0.23

1.20

4.06

2.51

1.37

2.89

$10.54 \quad 6.25$

$3.94 \quad 7.53$

17.75

6.48

8.03

11.90

$\begin{array}{llll}0.26 & 0.58 & 0.07 & 0.30\end{array}$

$\begin{array}{llll}19.87 & 63.88 & 4.48 & 28.33\end{array}$

Miscellaneous

1.76

$0.70 \quad 2.02$

888

889

890

891

892

893

894 
896 Table 3. Structure and components of the field risk assessment.

897

\begin{tabular}{|c|c|c|c|c|c|}
\hline & Factor & Description & Weighting & Low risk (1) & High risk (3) \\
\hline Source & $\mathrm{P}$ application risk & $\mathrm{P}$ balance & 0.8 & P deficit & P surplus \\
\hline \multicolumn{6}{|l|}{$*$} \\
\hline \multirow{4}{*}{ Mobilisation } & Desorption risk & $\begin{array}{l}\text { Organic matter } \\
\text { contents }\end{array}$ & 0.6 & $\begin{array}{l}\text { Mineral ( } \leq 20 \% \\
\text { OM) }\end{array}$ & $\begin{array}{l}\text { Histic (>20 \% } \\
\text { OM) }\end{array}$ \\
\hline & + & & & & \\
\hline & \multirow{2}{*}{ Detachment risk } & $\begin{array}{l}\text { Grassland - } \\
\text { poaching }\end{array}$ & 0.4 & $\begin{array}{l}\text { No signs of } \\
\text { poaching }\end{array}$ & $\begin{array}{l}\text { Clear signs of } \\
\text { poaching }\end{array}$ \\
\hline & & $\begin{array}{l}\text { Grassland or } \\
\text { Arable - erosion }\end{array}$ & 0.4 & $\begin{array}{l}\text { No signs of } \\
\text { erosion }\end{array}$ & $\begin{array}{l}\text { Clear signs of } \\
\text { erosion }\end{array}$ \\
\hline \multicolumn{6}{|l|}{$*$} \\
\hline \multirow{3}{*}{ Transport } & $\begin{array}{l}\text { Overland flow } \\
\text { risk }\end{array}$ & $\begin{array}{l}\text { Topographic } \\
\text { wetness index }\end{array}$ & 1 & $\begin{array}{l}\text { Driest } \\
\left(\leq P_{75}\right)\end{array}$ & $\begin{array}{l}\text { Wettest } \\
\left(>P_{75}\right)\end{array}$ \\
\hline & + & & & & \\
\hline & Connectivity risk & $\begin{array}{l}\text { Surface drainage } \\
\text { features }\end{array}$ & 0.6 & $\begin{array}{l}\text { Least connected } \\
\left(\leq P_{75}\right)\end{array}$ & $\begin{array}{l}\text { Most connected } \\
\left(>P_{75}\right)\end{array}$ \\
\hline
\end{tabular}

898 